\title{
Environmental Soil Phosphorus Threshold under No- Tillage and Swine Manure Application
}

\author{
Sérgio Walace Bousfield ${ }^{1}$ \\ https://orcid.org/0000-0002-0195-926X \\ Nerilde Favaretto ${ }^{1^{*}}$ \\ https://orcid.org/0000-0002-7405-8358 \\ Antônio Carlos Vargas Motta ${ }^{1}$ \\ https://orcid.org/0000-0001-9117-1881
}

\author{
Gabriel Barth ${ }^{2}$
}

https://orcid.org/0000-0002-8669-0588

Luana Salete Celante ${ }^{1}$

https://orcid.org/0000-0002-6241-1193

Verediana Fernanda Cherobim ${ }^{1}$
https://orcid.org/0000-0003-2981-7332

${ }^{1}$ Federal University of Paraná, Department of Soil Science and Agricultural Engineering, Curitiba, Paraná, Brazil; ${ }^{2}$ Foundation for Agricultural Assistance and Technical Divulgation, Curitiba, Paraná, Brazil.

Received: 2019.09.10; Accepted: 2020.02.28.

${ }^{*}$ Correspondence: nfavaretto@ufpr.br; Tel: +55-41-3350-5638

\section{HIGHLIGHTS}

- Swine manure and mineral fertilizer increased soil P contents.

- High doses of swine manure and mineral fertilizer surpassed the environmental soil P threshold.

- P saturated soils represent an environmental risk.

\begin{abstract}
Swine manure is applied in agricultural fields as a source of nutrients for plant growth, however, excessive application over the years can promote soil phosphorus $(P)$ accumulation. The objective of this study was to establish the environmental soil P threshold based on the degree of P saturation (DPS), as well, to evaluate the soil $P$ storage capacity. The experiment was carried out in an Oxisol (sandy clay loam texture), under no-tillage and crop rotation. Treatments consisted of four annual doses of liquid swine manure $(0,100$, 200 , and $300 \mathrm{~m}^{3} \mathrm{ha}^{-1}$ year-1), and three doses of mineral fertilizer $(0,50$, and $100 \%$ of the crop nutrients requirement), in a randomized block with split-plot design (four replications). Soil $P$ content was analyzed by $\mathrm{P}_{\text {Mehlich-1, }} \mathrm{P}_{\mathrm{CaCl}}$, water-soluble $\mathrm{P}$ (WSP) and total $\mathrm{P}$. The application of swine manure and mineral fertilizer increased soil $P$ contents mainly at $0-10 \mathrm{~cm}$ depth. The DPS corresponding to the change point was $14.9 \%$ at depth $0-10$ and $8.6 \%$ at depth $0-20 \mathrm{~cm}$ with WSP and $18.7 \%$ at $0-10 \mathrm{~cm}$ and $8.9 \%$ at $0-20 \mathrm{~cm}$ depth with $\mathrm{P}_{\text {CaCl2. }}$. The lowest change point value was DPS $8.6 \%$ which corresponds to $43 \mathrm{mg} \mathrm{kg}^{-1}$ of $\mathrm{P}_{\text {Mehlich-1 }}$, so, in practical terms, we suggest this value as the environmental soil $P$ threshold. The soil $P$ storage capacity indicated negative values with the higher doses of swine manure and mineral fertilizer which increases the vulnerability of $P$ loss by surface and subsurface hydrological transfer pathway.
\end{abstract}

Keywords: organic fertilization; degree of phosphorus saturation; environmental critical limit.

\section{INTRODUCTION}

Swine manure is applied in agricultural fields as a source of nutrients for plant growth, however, manure application without the criteria of crop nutrients requirement or even based only on crop nitrogen (N) requirement, which is a worldwide common practice, will over apply phosphorus $(P)$ [1]. Consecutive applications over the years will increase soil $P$ levels [2] and consequently the potential for increased $P$ losses by surface and subsurface hydrological transfer pathways [3]. In tropical and subtropical soils, P is a limiting 
nutrient for crop productivity and food production sustainability [4], so in intensive agricultural areas, $\mathrm{P}$ is continuously applied via mineral and organic fertilizers. However, the soil $\mathrm{P}$ accumulation by excessive fertilizer applications can result in $P$ losses to aquatic ecosystems causing the eutrophication process in freshwater bodies [5-7]. The risk of $P$ transport from soil to aquatic ecosystems may be associated with the degree of phosphorus saturation (DPS) in the soil [8].

The DPS is a tool to indicate the risk of soil P loss from agricultural areas [8-10] and was originally used in Netherlands to estimate the critical environmental soil $P$ level in sandy soils [11]. DPS measures the intensity of $\mathrm{P}$ accumulation in relation to the soil capacity to adsorb $\mathrm{P}$ and is related to the desorption potential of the soil. Modifications of the DPS concept have been proposed in the literature [9] with the determination of the maximum soil $P$ saturation index, which represents the change point with an abrupt increase in soil $P$ solubility [6,12]. Therefore, the change point indicates the point of high $\mathrm{P}$ solubility which means an environmental risk of $P$ loss via surface and subsurface flow. The change point progressed to the concept of limit or critical or threshold environmental soil $\mathrm{P}$, which refers to the soil $\mathrm{P}$ content corresponding to the change point $[13,14]$.

The change point is usually obtained by the relationship between DPS and soil P content extracted in water, $\mathrm{CaCl}_{2}$ or soil solution [15-19]. However, it also can be calculated based on runoff soluble P content [7]. Also, studies with DPS have been done with different soil P test such as Mehlich-1, Mehlich-3, Olsen, ammonium oxalate and resin $[8,9,14,20]$. As different soil $P$ extractors have been used, also several ways of calculating DPS have been proposed, among them the maximum $\mathrm{P}$ adsorption capacity obtained by the Langmuir model or the $\mathrm{P}$ adsorption capacity estimated by the soil $\mathrm{Fe}+\mathrm{Al}$ content extracted with ammonium oxalate or Mehlich-1 [8,9,13,18,21].

The soil P storage capacity (SPSC) is defined using the DPS concept [8] and represents the remaining capacity to support $\mathrm{P}$ application prior to reaching the DPS threshold and a condition of elevated risk of $\mathrm{P}$ loss [12,22].

The establishment of the environmental soil $\mathrm{P}$ threshold as well as the soil $\mathrm{P}$ storage capacity is important for making appropriate fertilizer recommendations ensuring the safety of the environment and the agricultural production $[8,9,23]$. These tools have been worldwide used to estimate the $P$ loss vulnerability and to recommend best management practices, however other tools to estimate $P$ loss risk in agricultural fields are being studied, such as the $P$ index, which considers not only the source but also the transport factors $[1,8,9]$.

The objective of this study was to establish the environmental soil $P$ threshold based on the degree of $P$ saturation, as well, to evaluate the soil P storage capacity in Oxisol (sandy clay loam texture) under no-tillage with mineral fertilizer and swine manure application over a three-years period.

\section{MATERIAL AND METHODS}

\section{Experimental site}

The experiment was conducted at Araguari Farm, Tibagi county $\left(24^{\circ} 33^{\prime} 18^{\prime \prime} \mathrm{S}, 50^{\circ} 27^{\prime} 58^{\prime \prime} \mathrm{W}, 890 \mathrm{~m}\right.$ altitude), Paraná state, Brazil. The regional climate is classified as $\mathrm{Cfb}$ - humid subtropical climate mesothermal (Köppen), with mild summer and an average annual rainfall of $1700 \mathrm{~mm}$, without a dry season [24].

Experimental units were installed in October 2010, in Oxisol (sandy clay loam texture) under no-tillage and crop rotation: corn (Zea mays L.) and soybean (Glycine max (L.) Merr.) in the summer, and wheat (Triticum aestivum L.) and oat (Avena sativa L.) in the winter. The soil chemical properties before the beginning of the experiment are presented in Table 1 and the particle size distribution were 210, 251 and $539 \mathrm{~g} \mathrm{~kg}^{-1}$ of clay, silt and sand at 0-10 cm depth and 227, 292 and $481 \mathrm{~g} \mathrm{~kg}^{-1}$ at $10-20 \mathrm{~cm}$ depth.

Table 1. Chemical properties of the investigated soil in 0-10 and 10-20 cm depth.

\begin{tabular}{|c|c|c|c|c|c|c|c|c|c|c|c|c|c|c|}
\hline \multirow{3}{*}{$\begin{array}{c}\text { Depth } \\
\mathrm{cm}\end{array}$} & \multirow{3}{*}{$\begin{array}{c}\mathrm{pH} \\
\mathrm{CaCl}_{2}\end{array}$} & & & \multicolumn{11}{|c|}{ Chemical properties } \\
\hline & & $\mathrm{Al}^{3+}$ & $\mathrm{H}+\mathrm{Al}$ & $\mathrm{Ca}^{2+}$ & $\mathrm{Mg}^{2+}$ & \multirow[t]{2}{*}{$\mathrm{K}^{+}$} & $\mathrm{P}_{\text {Mehlich-1 }}$ & WSP & $\mathrm{P}_{\mathrm{CaCl} 2}$ & \multirow{2}{*}{$\begin{array}{c}\mathrm{OC} \\
\mathrm{g} \mathrm{dm}^{-3}\end{array}$} & $\mathrm{Cu}$ & $\mathrm{Fe}$ & $\mathrm{Mn}$ & \multirow[t]{2}{*}{$\mathrm{Zn}$} \\
\hline & & \multicolumn{4}{|c|}{$\mathrm{cmol}_{\mathrm{c}} \mathrm{dm}^{-3}$} & & \multicolumn{3}{|c|}{$-\mathrm{mg} \mathrm{dm}^{-3}$} & & \multicolumn{3}{|c|}{$\mathrm{mg} \mathrm{dm}^{-3}$} & \\
\hline $0-10$ & 5.8 & 0.0 & 2.2 & 4,6 & 2.3 & 0.23 & 13.8 & 3.4 & 2.0 & 17.4 & 0.6 & 49 & 5.8 & 0.5 \\
\hline $10-20$ & 4.6 & 1.2 & 5.2 & 2.5 & 1.3 & 0.14 & 8.0 & 0.4 & 0.2 & 14.7 & 0.7 & 68 & 2.3 & 0.4 \\
\hline
\end{tabular}

$\mathrm{Cu}, \mathrm{Fe}, \mathrm{Mn}$ and $\mathrm{Zn}$ extracted with DTPA; WSP=water-soluble $\mathrm{P} ; \mathrm{OC}=$ organic carbon 
Treatments consisted of four annual doses of liquid swine manure $\left(0,100,200\right.$, and $300 \mathrm{~m}^{3}$ ha $^{-1}$ year $\left.{ }^{-1}\right)$, and three doses of mineral fertilizer $(0,50$, and $100 \%$ of the crop nutrients requirement (Table 4)). The experimental design was randomized blocks (four replications) with split-plot layout (plots with mineral fertilization and subplots with organic fertilization), totaling 12 treatments and 48 experimental units. Each experimental unit was $60 \mathrm{~m}^{2}(12 \mathrm{~m}$ by $5 \mathrm{~m})$.

The annual swine manure (SM) dose was split into two applications: half in the summer crop and half in the winter crop. The swine manure was manually applied with a watering can on the soil surface before sowing and the mineral fertilizer was applied in-furrow at sowing and some of the $\mathrm{N}$ was applied on coverage after sowing. The chemical properties of the SM applied since the beginning of the experiment (2010-2013) are presented in Table 2. The amount of $\mathrm{N}, \mathrm{P}$, and $\mathrm{K}$ applied by swine manure and by mineral fertilizer are presented in Table 3 and Table 4, respectively.

Table 2. Chemical properties of the swine manure applied since the experiment installation.

\begin{tabular}{|c|c|c|c|c|c|c|c|c|c|c|c|c|}
\hline Season crop & $\begin{array}{c}\text { Total solids } \\
\mathrm{g} \mathrm{L}^{-1}\end{array}$ & $\mathrm{~N}$ & $P$ & $\mathrm{~K}$ & $\mathrm{Ca}$ & $\mathrm{Mg}$ & $S$ & $B$ & $\mathrm{Cu}$ & $\begin{array}{c}\mathrm{Fe} \\
\mathrm{mg} \mathrm{L}^{-1}\end{array}$ & $\mathrm{Mn}$ & $\mathrm{Zn}$ \\
\hline Summ & 6.70 & 0.22 & 0.09 & 0.08 & 0.29 & 0.09 & 0.08 & 4.82 & nd & nd & nd & nd \\
\hline Winte & 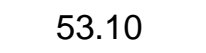 & 2.35 & 1.63 & 1.92 & 2.62 & 1.53 & 0.42 & 1.00 & 25.22 & 111.51 & 36.87 & 90.27 \\
\hline Summ & 45.70 & 1.61 & 1.50 & 1.49 & 1.98 & 1.85 & 0.43 & 26.46 & 16.79 & 137.10 & 31.08 & 59.41 \\
\hline Winter 2012 & nd & nd & nd & nd & nd & nd & nd & nd & nd & nd & nd & nd \\
\hline Summer $12 / 13$ & 13.40 & 0.27 & 0.35 & 0.19 & 0.55 & 0.42 & 0.23 & nd & nd & nd & nd & nd \\
\hline Mean (season) & 29.73 & 1.11 & 0.89 & 0.92 & 1.36 & 0.97 & 0.29 & 10.76 & 21.01 & 124.31 & 33.98 & 74.84 \\
\hline
\end{tabular}

nd: not determined

Table 3. Amount of nitrogen $(\mathrm{N})$, phosphorus $(\mathrm{P})$, and potassium $(\mathrm{K})$ applied in the winter and summer crops via swine manure $\left(50,100\right.$ e $150 \mathrm{~m}^{3}$ ha-1 $^{-1}$ season $\left.^{-1}\right)$.

\begin{tabular}{|c|c|c|c|c|c|c|c|c|c|}
\hline \multirow{3}{*}{ Season crop } & \multicolumn{3}{|c|}{$50 \mathrm{~m}^{3}$ ha $^{-1}$ season $^{-1}$} & \multicolumn{3}{|c|}{$100 \mathrm{~m}^{3}$ ha $^{-1}$ season $^{-1}$} & \multicolumn{3}{|c|}{$150 \mathrm{~m}^{3}$ ha $^{-1}$ season $^{-1}$} \\
\hline & $\mathrm{N}$ & $P$ & $\mathrm{~K}$ & $N$ & $P$ & $\mathrm{~K}$ & $\mathrm{~N}$ & $\mathrm{P}$ & $\mathrm{K}$ \\
\hline & \multicolumn{3}{|c|}{$\mathrm{kg} \mathrm{ha}^{-1}$} & \multicolumn{3}{|c|}{$\mathrm{kg} \mathrm{ha}^{-1}$} & \multicolumn{3}{|c|}{$\mathrm{kg} \mathrm{ha}^{-1}$} \\
\hline Summer $10 / 11$ & 11.0 & 4.5 & 4.0 & 22.0 & 9.0 & 8.0 & 33.0 & 13.5 & 12.0 \\
\hline Winter 2011 & 117.5 & 81.5 & 96.0 & 235.0 & 163.0 & 192.0 & 352.5 & 244.5 & 288.0 \\
\hline Summer $11 / 12$ & 80.5 & 75.0 & 74.5 & 161.0 & 149.0 & 149.0 & 241.5 & 223.5 & 223.5 \\
\hline Winter 2012 & 55.6 & 44.5 & 46.0 & 111.2 & 89.0 & 92.0 & 166.5 & 133.5 & 138.0 \\
\hline Summer $12 / 13$ & 13.5 & 17.5 & 9.5 & 27.0 & 35.0 & 19.0 & 40.5 & 52.5 & 28.5 \\
\hline Total & 278.1 & 223.0 & 230.0 & 556.2 & 445.0 & 460.0 & 834.0 & 667.5 & 690.0 \\
\hline Mean (season) & 55.6 & 44.6 & 46.0 & 111.2 & 89.0 & 92.0 & 166.8 & 133.5 & 138.0 \\
\hline
\end{tabular}

Table 4. Crop, sowing date, and amount of nitrogen $(\mathrm{N})$, phosphorus $(\mathrm{P})$ and potassium $(\mathrm{K})$ applied in the winter and summer season via mineral fertilizer (0,50 and $100 \%$ of the recommended dose).

\begin{tabular}{|c|c|c|c|c|c|c|c|c|c|c|c|}
\hline \multirow{2}{*}{ Season crop } & \multirow{2}{*}{ Crop } & \multirow{2}{*}{ Sowing date } & \multicolumn{3}{|c|}{$\mathrm{N}$} & \multicolumn{3}{|c|}{$P$} & \multicolumn{3}{|c|}{$\mathrm{K}$} \\
\hline & & & $0 \%$ & $50 \%$ & $100 \%$ & $0 \%$ & $50 \%$ & $100 \%$ & $0 \%$ & $50 \%$ & $100 \%$ \\
\hline & & & \multicolumn{3}{|c|}{$\ldots \mathrm{kg} \mathrm{ha}^{-1}$} & \multicolumn{3}{|c|}{$\ldots \mathrm{kg} \mathrm{ha}^{-1}$} & \multicolumn{3}{|c|}{$\ldots \mathrm{kg} \mathrm{ha}^{-1}$} \\
\hline Summer $10 / 11$ & Corn & 17/10/2010 & 0 & 94 & 189 & 0 & 22 & 44 & 0 & 75 & 150 \\
\hline Winter 2011 & Wheat & $11 / 06 / 2011$ & 0 & 60 & 120 & 0 & 13 & 26 & 0 & 25 & 50 \\
\hline Summer $11 / 12$ & Soybean & $29 / 11 / 2011$ & 0 & 0 & 0 & 0 & 13 & 26 & 0 & 25 & 50 \\
\hline Winter 2012 & Oat & $17 / 05 / 2012$ & 0 & 57 & 114 & 0 & 19 & 39 & 0 & 25 & 50 \\
\hline Summer $12 / 13$ & Soybean & 08/11/2012 & 0 & 0 & 0 & 0 & 13 & 26 & 0 & 25 & 50 \\
\hline Total & & & 0 & 211 & 423 & 0 & 80 & 161 & 0 & 175 & 350 \\
\hline Mean (season) & & & 0 & 42 & 85 & 0 & 16 & 32 & 0 & 35 & 70 \\
\hline
\end{tabular}




\section{Soil sampling and analysis}

Soil samples were collected in April 2013, at two depths (0-10 and 10-20 cm). The samples were air-

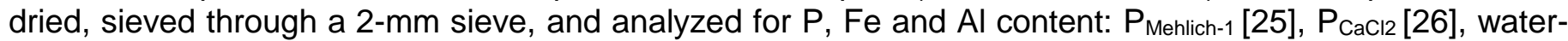

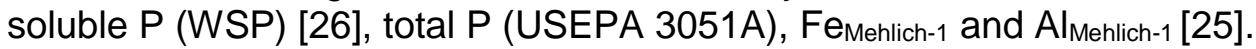

WSP extraction was carried out shaking soil samples at 1:10 soil:deionized water for one hour. Then, the samples were centrifuged and filtered through a cellulose membrane of $0.45 \mu \mathrm{m}$. The same procedure was used for the extraction of $\mathrm{P}$ using a $0.01 \mathrm{~mol} \mathrm{~L}^{-1} \mathrm{CaCl}_{2}$ solution $\left(\mathrm{P}_{\mathrm{CaCl}}\right)$. The $\mathrm{P}$ determination was by inductively coupled plasma - optical emission spectrometry (ICP-OES).

For Mehlich-1 extraction, $10 \mathrm{~g}$ of soil was stirred in $100 \mathrm{~mL}$ of solution $\left(0.0125 \mathrm{~mol} \mathrm{~L}^{-1} \mathrm{H}_{2} \mathrm{SO}_{4}+0.0050\right.$ mol L-1 $\mathrm{HCl}$ ) for five minutes and allowing to decant for approximately fifteen hours. After separation of the extract (supernatant), an aliquot was filtered through a cellulose membrane of $0.45 \mu \mathrm{m}$ and $\mathrm{P}, \mathrm{Fe}$ and $\mathrm{Al}$ determined by ICP-OES.

For total P extraction by the microwave method (USEPA 3051A), $0.25 \mathrm{~g}$ of soil (particle size $<0.2 \mathrm{~mm}$ ) was transferred to Teflon tubes in the presence of $9 \mathrm{~mL}$ of concentrated $\mathrm{HNO}_{3}$ and $3 \mathrm{~mL}$ of concentrated $\mathrm{HCl}$. The tubes were sealed and kept in the microwave for 8 minutes and 40 seconds to raise the temperature to $175^{\circ} \mathrm{C}$, this temperature was maintained for an additional 4 minutes and 30 seconds. After digestion, the suspension was filtered through a cellulose membrane of $0.45 \mu \mathrm{m}$ and P determined by ICP-OES.

\section{Degree of phosphorus saturation (DPS), change point (CP), and soil P storage capacity (SPSC)}

The degree of phosphorus saturation in the soil was calculated using Mehlich-1 extractable $\mathrm{P}, \mathrm{Al}$, and Fe (Equation 1) [14] where DPS is the degree of phosphorus saturation (\%); $\alpha=0.5$ is an empirical factor; $\mathrm{P}_{\mathrm{M} 1 / 31}, \mathrm{Fe}_{\mathrm{M} 1 / 56}$ and $\mathrm{Al}_{\mathrm{M} 1 / 27}$ extracted by Mehlich-1 in mol.

$$
D P S=\frac{P_{M 1} / 31}{\alpha *\left(F e_{M 1} / 56\right)+\left(A l_{M 1} / 27\right)} \times 100
$$

The change point was obtained by plotting DPS vs. $\mathrm{P}_{\mathrm{CaCl}}$ and DPS vs. WSP, which was modelled as segmented linear regressions of two segments with different angular coefficients. The change point is the intercept. The Equation 2 represents the segment below the change point and the Equation 3 represents the segment above the change point:

$$
\begin{aligned}
& D P S_{W S P \text { PCaCl2 }}=\frac{[y 1(C P-D P S)+y 2(D P S-t 1)]}{C P-t 1}, t 1 \leq D P S \leq C P \\
& D P S_{W S P \text { PCaCl2 }}=\frac{[y 2(t 2-D P S)+y 3(D P S-C P)]}{t 2-C P}, C P \leq D P S \leq t 2
\end{aligned}
$$

Where CP is the change point in DPS, $\mathrm{t} 1$ is the lowest value of DPS, $\mathrm{t} 2$ is the highest value of DPS, and $y 1, y 2$, and $y 3$ are model adjustment variables. The four variables ( $y 1, y 2$, y3, and CP) were estimated by the segmented linear regression model with the SIGMAPLOT 12.0 (Systat Software Inc.) statistical package. The DPS and CP were calculated in the depths of 0-10, 10-20 and 0-20 cm.

The soil P storage capacity (SPSC) was obtained from the DPS and CP values according to Equation 4 [22].

$$
\text { SPSC }\left(m g k g^{1}\right)=((\text { Threshold DPS - Soil DPS })) *\left(\left(F e_{M 1} / 56\right)+\left(\left(A l_{M 1} / 27\right)\right) * 31\right.
$$

Where threshold DPS is the DPS value at change point, soil DPS is the DPS of the soil under investigation, and $\mathrm{Fe}_{\mathrm{M} 1 / 56}$ and $\mathrm{Al}_{\mathrm{M} 1 / 27}$ extracted by Mehlich-1 in mol which represents the $\mathrm{P}$ adsorption capacity of the investigated soil, being the SPSC calculated for the depth of 0-10 cm.

\section{Environmental soil $\mathbf{P}$ threshold}

Soil P environmental critical level was defined as the value of the change point in DPS being transformed into soil $\mathrm{P}_{\text {Mehlich-1 }}$ content by the regression equation with DSP and soil $\mathrm{P}_{\text {Mehlich-1. }}$ 


\section{Statistical analyses}

The Tukey test $(p<0.05)$ was applied to mean comparison. Linear regression and correlation analysis were performed between $P$ extracted by different methods. The statistical analysis was performed with the SIGMA PLOT 12.0 (Systat Software Inc.).

\section{RESULTS}

\section{Phosphorus in soil}

There was no statistically significant interaction between swine manure and mineral fertilizer, so the mean of the treatments was compared and discussed separately.

The phosphorus content increased with mineral fertilizer mainly in the surface layer $(0-10 \mathrm{~cm})$ resulting higher values in the $100 \%$ mineral fertilizer treatment (Table 5). The $P_{\text {Mehlich-1 }}$ and total $P$ was $95 \%$ and $20 \%$ higher, respectively, compared to treatment without fertilization (control).

Table 5. Soil phosphorus contents $\left(\mathrm{mg} \mathrm{kg}^{-1}\right)$ in the mineral fertilizer treatments with different extraction methods in 0-10 and $10-20 \mathrm{~cm}$ depth

\begin{tabular}{|c|c|c|c|c|}
\hline Mineral fertilizer & $P_{\text {Mehlich-1 }}$ & WSP & $\mathrm{P}_{\mathrm{CaCl} 2}$ & Total $\mathbf{P}$ \\
\hline$\%$ & \multicolumn{4}{|c|}{$0-10 \mathrm{~cm}$} \\
\hline 0 & 36.92 b & $6.26 \mathrm{~ns}$ & $0.59 \mathrm{~ns}$ & $330.3 \mathrm{~b}$ \\
\hline 50 & $49.89 \mathrm{~b}$ & $7.13 \mathrm{~ns}$ & $0.89 \mathrm{~ns}$ & $349.2 \mathrm{~b}$ \\
\hline 100 & $71.96 \mathrm{a}$ & $9.27 \mathrm{~ns}$ & $0.87 \mathrm{~ns}$ & $397.6 \mathrm{a}$ \\
\hline$\%$ & \multicolumn{4}{|c|}{$10-20 \mathrm{~cm}$} \\
\hline 0 & $8.50 \mathrm{~b}$ & $2.67 \mathrm{~ns}$ & $0.23 \mathrm{~b}$ & $178.9 \mathrm{~ns}$ \\
\hline 50 & $10.48 a b$ & $2.32 \mathrm{~ns}$ & $0.28 a b$ & $170.7 \mathrm{~ns}$ \\
\hline 100 & $13.36 \mathrm{a}$ & $2.28 \mathrm{~ns}$ & $0.32 \mathrm{a}$ & $203.8 \mathrm{~ns}$ \\
\hline
\end{tabular}

Means followed by the same letter are not significantly different by Tukey's test $(P<0.05)$; ns: not significant

The swine manure application also increased the soil $P$ content mainly in the surface layer $(0-10 \mathrm{~cm})$, being the greater values for all extractors in the $300 \mathrm{~m}^{3}$ ha $^{-1}$ year $^{-1} \mathrm{SM}$ dose (Table 6). The total $\mathrm{P}$ content was $58 \%$ superior when compared to the control treatment. Referring to $\mathrm{P}_{\text {Mehlich-1 }}$, WSP and $\mathrm{P}_{\mathrm{CaCl}}$, the values were around $219 \%, 149 \%$ and $113 \%$ higher than the treatment without fertilization (Table 6).

In the depth 10-20 cm, a significant increase in $P_{\text {Mehlich-1 }}$ was also observed with mineral fertilizer (Table 5 ) as well as with manure application (Table 6), indicating $P$ mobility in the soil profile.

Table 6. Soil phosphorus contents $\left(\mathrm{mg} \mathrm{kg}^{-1}\right)$ in the swine manure (SM) treatments with different extraction methods at depth of $0-10$ and $10-20 \mathrm{~cm}$.

\begin{tabular}{|c|c|c|c|c|}
\hline SM & $\mathbf{P}_{\text {Mehlich-1 }}$ & WSP & $\mathbf{P}_{\mathrm{CaCl} 2}$ & Total P \\
\hline$\left(m^{3}\right.$ ha $^{-1}$ year $\left.^{-1}\right)$ & \multicolumn{4}{|c|}{$0-10 \mathrm{~cm}$} \\
\hline 0 & 25.97 b & $4.58 \mathrm{c}$ & $0.51 \mathrm{~b}$ & $276.10 \mathrm{~d}$ \\
\hline 100 & $35.83 b$ & $6.09 \mathrm{bc}$ & $0.72 b$ & $328.64 \mathrm{c}$ \\
\hline 200 & $67.16 \mathrm{a}$ & $8.13 b$ & $0.82 a b$ & $395.66 \mathrm{~b}$ \\
\hline 300 & $82.75 \mathrm{a}$ & $11.41 \mathrm{a}$ & $1.09 \mathrm{a}$ & $435.63 a$ \\
\hline$\left(m^{3}\right.$ ha $^{-1}$ year $\left.^{-1}\right)$ & \multicolumn{4}{|c|}{$10-20 \mathrm{~cm}$} \\
\hline 0 & $7.56 \mathrm{c}$ & $2.24 \mathrm{~ns}$ & $0.29 \mathrm{~ns}$ & $177.71 \mathrm{~ns}$ \\
\hline 100 & 9.08 bc & $2.50 \mathrm{~ns}$ & $0.25 \mathrm{~ns}$ & $180.21 \mathrm{~ns}$ \\
\hline 200 & $12.60 \mathrm{ab}$ & $2.47 \mathrm{~ns}$ & $0.31 \mathrm{~ns}$ & $177.60 \mathrm{~ns}$ \\
\hline 300 & $13.88 \mathrm{a}$ & $2.48 \mathrm{~ns}$ & $0.28 \mathrm{~ns}$ & $202.41 \mathrm{~ns}$ \\
\hline
\end{tabular}

Means followed by the same letter are not significantly different by Tukey's test $(P<0.05)$; ns: not significant

The correlation coefficients obtained between the soil $\mathrm{P}$ content extracted by the different methods at depth of $0-10 \mathrm{~cm}$ were significant in all extractors ( $P_{\text {Mehlich-1, }}, \mathrm{WSP}, \mathrm{P}_{\mathrm{CaCl}}$ and Total $\mathrm{P}$ ) with values ranging between 0.82 and 0.96 . The highest correlation coefficient was 0.96 between $P_{\text {Mehlich-1 }}$ and total $P$ at depth of 0-10 cm. The correlation coefficients were not significant at $10-20 \mathrm{~cm}$ depth for all extractors. 


\section{Degree of phosphorus saturation (DPS) and Change point (CP)}

The relationship between WSP and DPS and between $\mathrm{P}_{\mathrm{CaCl} 2}$ and DPS resulted in a change point at depth of $0-10 \mathrm{~cm}$ (Figure 1A, 1D) and 0-20 cm (Figure 1C, 1F), while at depth of 10-20 cm was not found a change point (Figures 1B, 1E). The change point with WSP, in the depth of $0-10 \mathrm{~cm}$, was obtained at DPS $14.9 \%$ (Figure $1 \mathrm{~A}$ ), which corresponds to $73.29 \mathrm{mg} \mathrm{kg}^{-1}$ of $\mathrm{P}_{\text {Mehlich-1 }}$ (Figure 2) and at DPS $18.7 \%$ with $\mathrm{P}_{\mathrm{CaCl}}$ (Figure 1D), corresponding to $91.14 \mathrm{mg} \mathrm{kg}^{-1}$ of $P_{\text {Mehlich-1 }}$ (Figure 2). In the depth of 0-20 $\mathrm{cm}$, the change point was obtained at DPS 8.6\% to WSP (Figure 1C), corresponding to $43.12 \mathrm{mg} \mathrm{kg}^{-1}$ of $\mathrm{P}_{\text {Mehlich-1 }}$ (Figure 2) and at DPS $8.9 \%$ to $\mathrm{P}_{\mathrm{CaCl} 2}$ (Figure $1 \mathrm{~F}$ ) that corresponds to $55.51 \mathrm{mg}$ of $\mathrm{P}_{\text {Mehlich-1 }}$ (Figure 2).

(A)

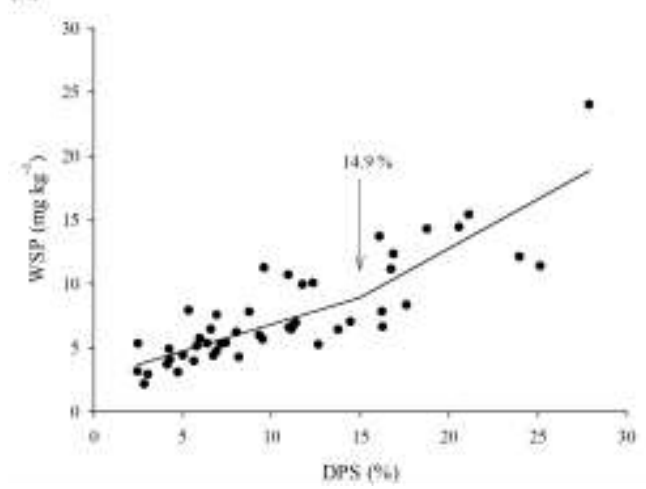

(8)

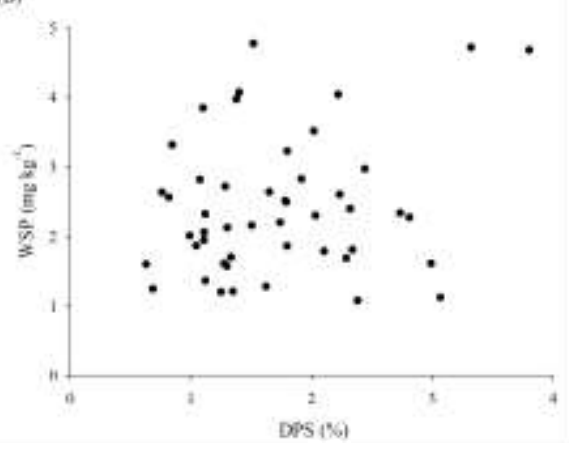

(C)

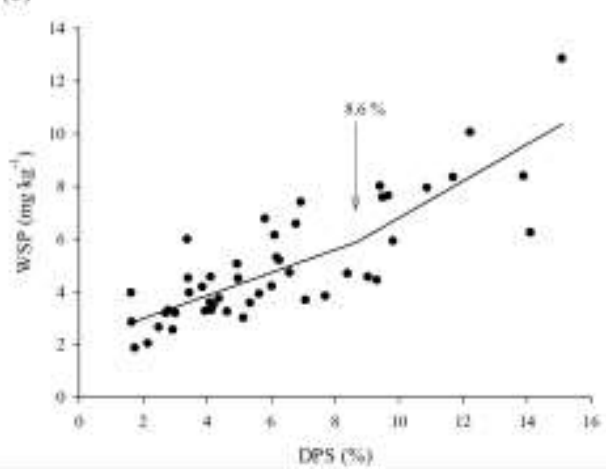

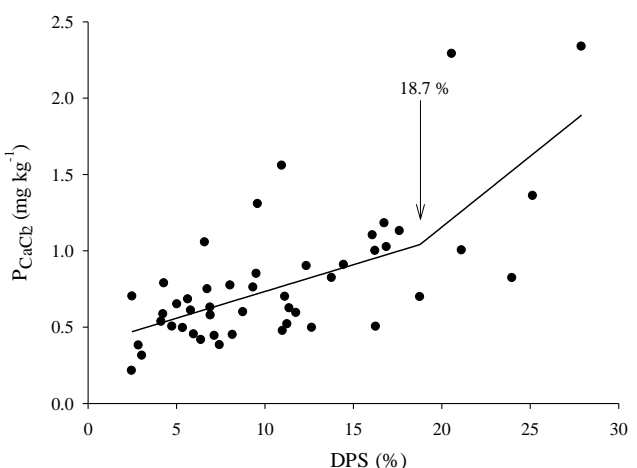

(E)
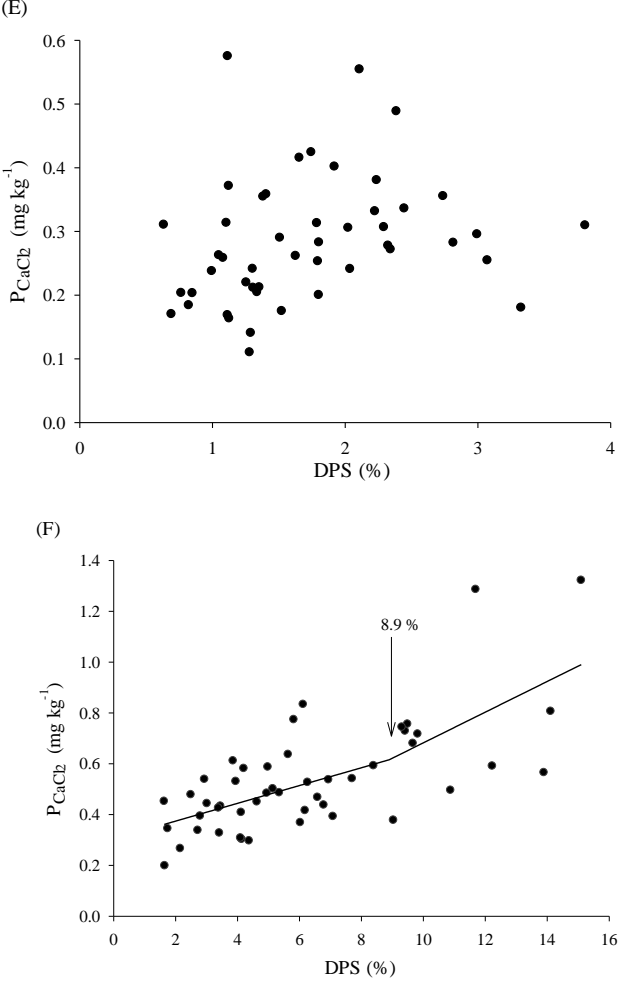

Figure 1. Relationship between WSP and degree of phosphorus saturation (DPS) calculated by Mehlich-1 at depths of 0-10 cm (A), 10-20 cm (B) and 0-20 cm (C) and relationship between $\mathrm{P}_{\mathrm{CaCl}}$ and DPS calculated by Mehlich-1 at depths of $0-10 \mathrm{~cm}(\mathrm{D}), 10-20 \mathrm{~cm}(\mathrm{E})$ and $0-20 \mathrm{~cm}(\mathrm{~F})$.

The estimated parameters and $\mathrm{R}^{2}$ values for the segmented linear regression model used to obtain the change point are presented in Table 7. WSP had the better statistic adjustment $\left(R^{2}=0.72\right.$ at depth of $0-10$ $\mathrm{cm} ; \mathrm{R}^{2}=0.68$ at depth of $0-20 \mathrm{~cm}$ ). 
Table 7. Generated equations and $R^{2}$ values adjusted in the linear regression model for change point with WSP and $\mathrm{P}_{\mathrm{CaCl}}$ at depths of $0-10$ and $0-20 \mathrm{~cm}$.

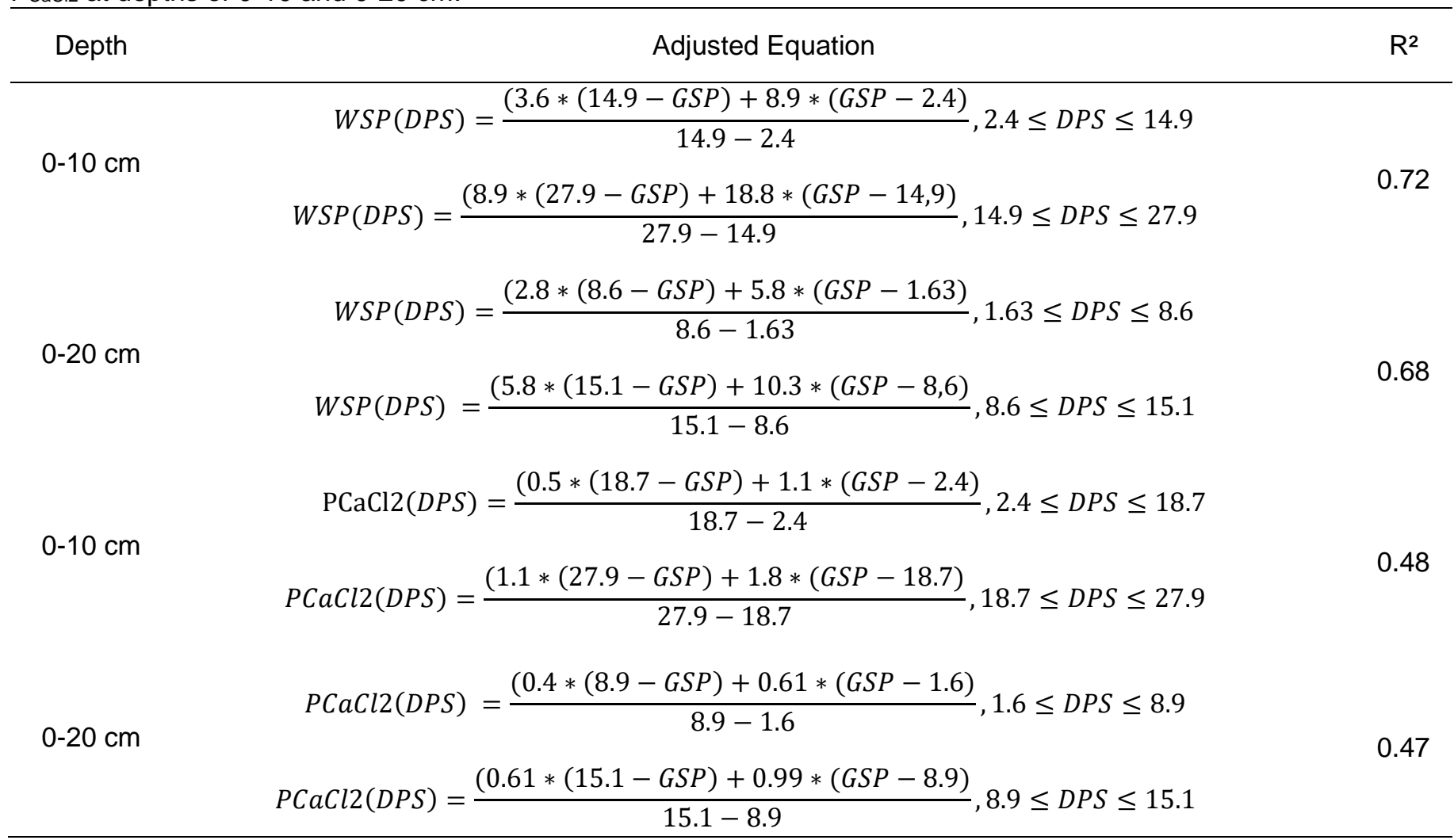

The DPS increased linearly with increasing soil $P_{\text {Mehlich-1 }}$ (Figure 2$)$. The high regression coefficient $\left(R^{2}=\right.$

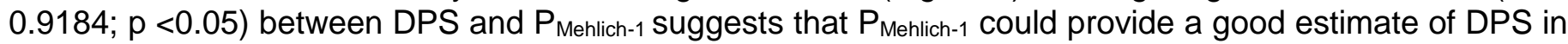
soils with similar conditions of our study. The best result of this regression analysis was obtained considering all data from depths of $0-10$ and $10-20 \mathrm{~cm}$. From this regression, we calculated the soil $P$ content correspondent to the change point, which was suggested as the environmental soil P threshold.

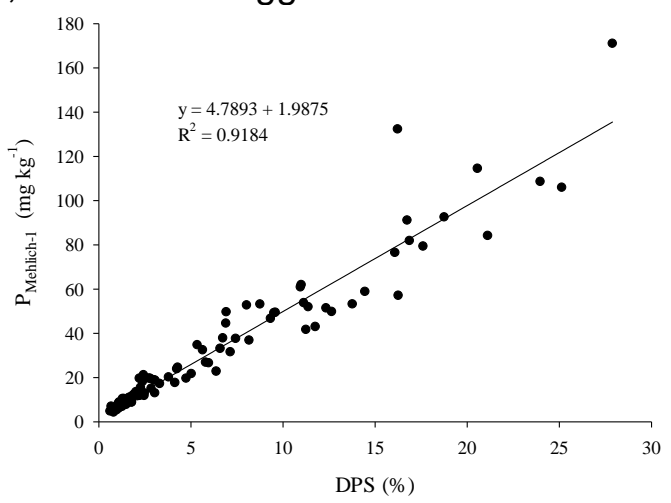

Figure 2. Relationship between degree of phosphorus saturation (DPS) and $P_{\text {Mehlich-1 }}$ in the soil samples of 0-10 and $10-20 \mathrm{~cm}$ depth.

\section{Environmental soil $\mathbf{P}$ threshold}

The environmental soil $P$ threshold was suggested from the smaller change point value obtained by the relation between DPS and WSP or DPS and $\mathrm{P}_{\mathrm{CaCl}}$. In our study the smaller change point was obtained at DPS $8.6 \%$ to WSP, equivalent to $43.12 \mathrm{mg} \mathrm{kg}^{-1}$ of $P_{\text {Mehlich-1 }}$ in the depth of $0-20 \mathrm{~cm}$ (Figure 1C) and at DPS $8.9 \%$ with $\mathrm{P}_{\mathrm{CaCl}}$, corresponding to $55.51 \mathrm{mg} \mathrm{kg}^{-1}$ of $\mathrm{P}_{\text {Mehlich-1 }}$ (Figure $1 \mathrm{~F}$ ).

\section{Soil P storage capacity (SPSC)}

The relationship between the SPSC and WSP at depth of $0-10 \mathrm{~cm}$, shows that WSP is minimal when SPSC is positive, however when SPSC is negative, the WSP is higher, which means that the solubility of soil $P$ is increased (Figure 3). 
The SPSC at depth of $0-10 \mathrm{~cm}$ shows that treatments with just one fertilizer type (mineral or swine manure) or with two fertilizer type but with lower doses, result in a positive storage capacity (Figure 4), which means, this soil support new $\mathrm{P}$ addition before reaching de environmental soil $\mathrm{P}$ threshold. On the other hand, treatments with mineral fertilizer (50 and 100\%) plus swine manure (200 and $300 \mathrm{~m}^{3} \mathrm{ha}^{-1}$ year ${ }^{-1}$ ) the SPSC is negative, which means that the soil $\mathrm{P}$ is above of the environmental soil $\mathrm{P}$ threshold and no more $\mathrm{P}$ should be applied.

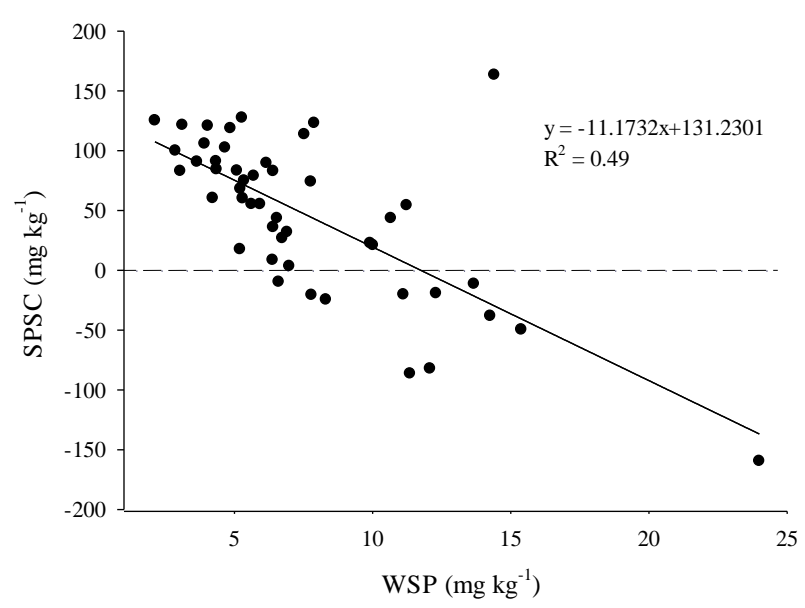

Figure 3. Relationship between soil P storage capacity (SPSC) and water-soluble P (WSP) at depth of $0-10 \mathrm{~cm}$ in soil with application of swine manure and mineral fertilizer.

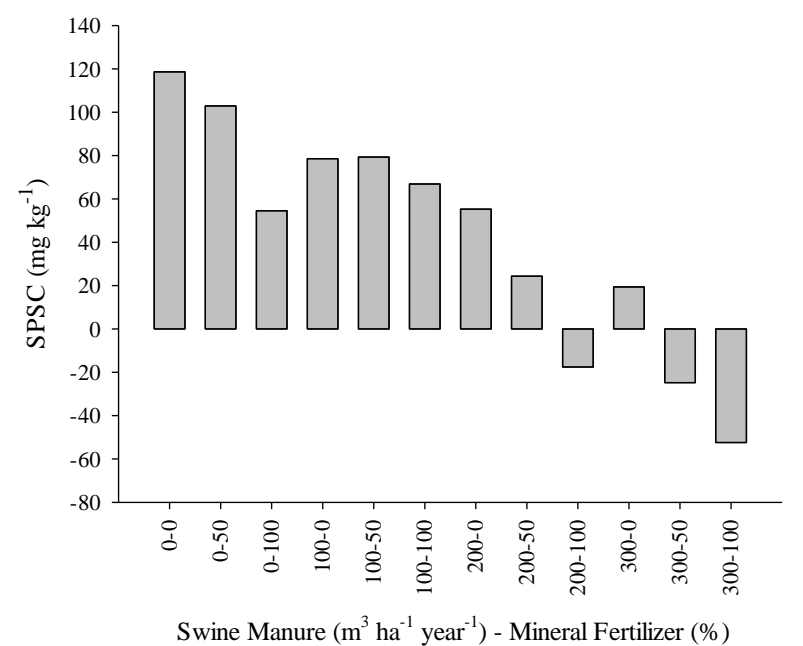

Figure 4. Soil P storage capacity (SPSC) at depth of $0-10 \mathrm{~cm}$ in soil with application of swine manure and mineral fertilizer.

\section{DISCUSSION}

The soil $P$ content was increased by application of mineral fertilizer (Table 5) and swine manure (Table 6) mainly in the $0-10 \mathrm{~cm}$ depth. The increment of soil $P$ content with these amendments was expected since a great amount of $P$ was applied in the higher doses (Tables 3 and 4). In no-tillage systems, the mineral fertilizers are applied in the seeding line, which results in a saturation zone with most of the $P$ adsorption sites occupied by the applied P. In this saturated zones, the $\mathrm{P}$ availability to crops can be enhanced because of the low energy bound between $P$ and the soil matrix [28].

Swine manure in the no-tillage system is applied at soil surface without incorporation, so the effect of successive mineral and organic fertilizations in no-tillage systems will be expected mainly at the soil surface layer [27-31]. The effect of the manure application on soil $P$ content was much greater compared to the mineral fertilizer which is explained by the high amount of $P$ applied with manure. During the three years period of study, $668 \mathrm{~kg} \mathrm{ha}^{-1}$ of $P$ was applied with the highest dose of swine manure (Table 3) and $161 \mathrm{~kg} \mathrm{ha}^{-}$ ${ }^{1}$ of $P$ applied with the highest dose of mineral fertilizer (Table 4).

The low mobility of soil $P$ is expected due to the high binding energy to functional groups of the mineral fraction, mainly $\mathrm{Fe}$ and $\mathrm{Al}$ oxides [31,32]. However, our data shows the effect of mineral fertilizer and swine manure also in the 10-20 cm depth. The $\mathrm{P}_{\text {Mehlich-1 }}$ was $95 \%$ higher in the $100 \%$ mineral fertilizer compared to the control (unamended treatment) in the $0-10 \mathrm{~cm}$ depth and $57 \%$ in the $10-20 \mathrm{~cm}$ depth (Table 5). The 
highest dose of manure was $219 \%$ higher compared to the control (unamended treatment) in the $0-10 \mathrm{~cm}$ depth and $84 \%$ in the $10-20 \mathrm{~cm}$ depth.

The relationship between WSP and DPS and between $\mathrm{P}_{\mathrm{CaCl}}$ and DPS resulted in a change point in the depths of $0-10 \mathrm{~cm}$ and $0-20 \mathrm{~cm}$ (Figure 1). The change point values with $\mathrm{P}_{\mathrm{CaCl} 2}$ were higher to that found with WSP in both depths, corroborating with other results [33]. The extraction of $P$ with $0.01 \mathrm{M} \mathrm{CaCl}_{2}$ aims to simulate the saline state in the soil solution [34] and estimates the $\mathrm{P}$ concentration in the soil solution or the $P$ fraction easily soluble [35]. However, in our study, the change point with WSP had the lower results and the better statistic adjustment (Table 7), so we suggested the environmental soil P threshold based on WSP at $0-20 \mathrm{~cm}$ depth.

Assuming lower values of change point means more rigor on the establishment of the environmental soil $P$ threshold. The WSP is frequently used to assess the risk of $P$ losses in agricultural areas, for example, correlating it with the dissolved P concentrations in the runoff or with the DPS [36-38]. Several studies using the DPS as a tool to obtain a phosphorus environmental critical threshold can be found in the literature $[9,13,18,39,40]$, and this tool is worldwide used to estimate the risk of water pollution in agricultural fields. In Brazil, in the state of Santa Catarina, the environmental soil phosphorus threshold has been proposed to regulate by law the swine manure application [16,21].

In our study, the lower change point was obtained at DPS $8.6 \%$ to WSP in the $0-20 \mathrm{~cm}$ depth, which is equivalent to $43.12 \mathrm{mg} \mathrm{kg}^{-1}$ of $P_{\text {Mehlich-1 }}$ (Figure $1 \mathrm{C}$ ), so $43 \mathrm{mg} \mathrm{kg}^{-1}$ of $P_{\text {Mehlich-1 }}$ is the suggested environmental soil $P$ threshold. Other studies with change point were carried out in Brazil $[16,18,19,21]$. Recently, in a study with dairy liquid manure and no-tillage in sandy clay loam texture [18] found a value of environmental soil $P$

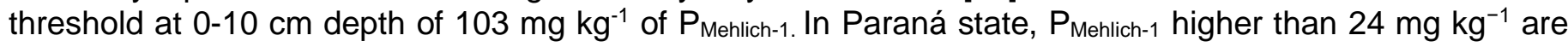
classified as very high for annual crops in soils with clay content lower than $25 \%$ [41]. So, the environmental soil $P$ threshold suggested is above the optimal agronomic soil $P$ level. Thus, agricultural soils with $P_{\text {Mehlich-1 }}$ values below the environmental soil $P$ critical level will have a low risk of environmental pollution and will not be a problem for agricultural production.

By using the SPSC data, it is possible to estimate the remaining soil storage capacity, and this information is very useful for soil $P$ management [42]. Positive values of SPSC means that the soil acts a $P$ sink; and negative values, the soil acts as a P source. So, the SPSC can be used to estimate the amount of $P$ that can be added to the soil before the soil becomes an environmental risk $[9,10]$. Our results indicate that after three-years period with mineral and organic fertilization in a sandy clay loam soil under no-tillage, the treatments with mineral fertilizer (50 and 100\%) plus swine manure (200 and $300 \mathrm{~m}^{3} \mathrm{ha}^{-1}$ year ${ }^{-1}$ ) acts as a source of $P$ (negative SPSC), which means that the soil $P$ is above of the environmental soil $P$ threshold and there is no remaining storage capacity and so no more $P$ should be applied.

The inadequate and excessive $P$ application, via organic and mineral sources, can cause $P$ accumulation in the soil and consequently loss of this nutrient to water bodies. In this sense, the use of tools which improve $P$ fertilizer management in agricultural areas are essential to ensure that the $P$ applied to the soil does not become a potential polluting source.

\section{CONCLUSIONS}

Swine manure and mineral fertilizer application increased soil P contents mainly in the 0-10 cm depth. The increment of soil $P$ content was greater with swine manure application.

The environmental soil $P$ threshold was suggested from the lower change point value and this was obtained with DPS vs. WSP in the $0-20 \mathrm{~cm}$ depth, which corresponds to $8.6 \%$ DPS. So, in practical terms, we suggest $43 \mathrm{mg} \mathrm{kg}^{-1}$ of $\mathrm{P}_{\text {Mehlich-1 }}$ as the environmental soil $\mathrm{P}$ threshold for this Oxisol (sandy clay loam texture) under no-tillage with application of swine manure and mineral fertilizer.

The soil P storage capacity indicated negative values with the higher doses of swine manure and mineral fertilizer which increases the P loss vulnerability by surface and subsurface hydrological transfer pathway.

Acknowledgements: The authors are grateful to National Council for Scientific and Technological Development (CNPq/Brazil), Coordination for the Improvement of Higher Education Personnel (CAPES/Brazil), Foundation to Support the Scientific and Technological Development of Paraná State (Araucaria Foundation/ Parana/Brazil) for the financial support (grants and scholarships) and to Foundation for Agricultural Assistance and Technical Divulgation (ABC Foundation) for the field support. 


\section{REFERENCES}

1. Sharpley A, Wang X. Managing agricultural phosphorus for water quality: Lessons from the USA and China. J Environ Sci. 2014 Sep;26(9):1770-82. doi:10.1016/j.jes.2014.06.024.

2. Hooda PS, Edwards AC, Anderson HA, Miller A. A review of water quality concerns in livestock farming areas. Sci Total Environ. 2000 Apr;250(1-3):143-67. doi:10.1016/S0048-9697(00)00373-9.

3. Leinweber P, Turner BL, Meissner R. Phosphorus. In: Haygart PM, Jarvis JS, editors. Agriculture, hydrology and water quality. Wallingford: CABI Publishing; 2002. p. 29-56.

4. Haygarth PM, Bardgett RD, Condron LM. Nitrogen and phosphorus cycles and their management. In: Gregory PJ, Nortcliff S, editors. Soil conditions and plant growth. Oxford: Blackwell Publishing Ltda; 2013. p. 132-59.

5. Schelske CL. Eutrophication: Focus on phosphorus. Science. 2009 May;324(5928):721-22. doi:10.1126/science.324_722.

6. Sims JT, Simard RR, Joern BC. Phosphorus loss in agricultural drainage: Historical perspective and current research. J Environ Qual. 1998 Mar;27(2):277-93. doi:10.2134/jeq1998.00472425002700020006x.

7. Sharpley AN, Mcdowell RW, Kleinman PJA. Phosphorus loss from land to water: Integrating agricultural and environmental management. Plant Soil. 2001 Dec;237(2):287-307. doi:10.1023/A:1013335814593.

8. Nair VD, Harris WG. A capacity factor as an alternative to soil test phosphorus in phosphorus risk assessment. New Zeal J Agric Res. 2004 Oct;47(4):491-7. doi:10.1080/00288233.2004.9513616.

9. Nair VD. Soil phosphorus saturation ratio for risk assessment in land use systems. Front Environ Sci. 2014 Apr;2(6):1-4. doi:10.3389/fenvs.2014.00006.

10. Dari B, Nair VD, Sharpley AN, Kleinman P, Franklin D, Harris WG. Consistency of the threshold phosphorus saturation ratio across a wide geographic range of acid soils. Agrosyst. Geosci. Environ. 2018 Sep;1(1):1-8. doi:10.2134/age2018.08.0028.

11. van der Zee SEATM, Fokkink LGJ, van Riemsdijk WH. A new technique for assessment of reversibly adsorbed phosphate. Soil Sci Soc Am J. 1987 May;51(3):599-64. doi: 10.2136/sssaj1987.03615995005100030009x.

12. Dari B, Nair VD, Harris WG. Approaches for evaluating subsurface phosphorus loss potential from soil profiles. Agric Ecosyst Environ. 2017 May;245(1):92-9. doi:10.1016/j.agee.2017.05.006.

13. Casson JP, Bennett DR, Nolan SC, Olson BM, Ontkean GR. Degree of phosphorus saturation thresholds in manure-amended soils of Alberta. J Environ Qual. 2006 Oct;35(6):2212-21. doi:10.2134/jeq2006.0085.

14. Nair VD, Portier KM, Graetz DA, Walker ML. An environmental threshold for degree of phosphorus saturation in sandy soils. J Environ Qual. 2004 Jan-Fev;33(1):107-13. doi:10.2134/jeq2004.1070.

15. Maguire RO, Sims JT. Soil testing to predict phosphorus leaching. J Environ Qual. 2002 Sep;31(5):1601-09. doi:10.2134/jeq2002.1601.

16. Gatiboni LC, Smyth TJ, Schmitt DE, Cassol PC, Oliveira CMB. Soil phosphorus thresholds in evaluating risk of environmental transfer to surface waters in Santa Catarina, Brazil. Rev Bras Ciência do Solo. 2015 Aug;39(4):1225-34. doi:10.1590/01000683rbcs20140461.

17. Wang YT, O'Halloran IP, Zhang TQ, Hu QC, Tan CS. Phosphorus sorption parameters of soils and their relationships with soil test phosphorus. Soil Sci Soc Am J. 2015 Jan;79(2):672-80. doi:10.2136/sssaj2014.07.0307

18. Abboud FY, Favaretto N, Motta ACV, Barth G, Goularte GD. Phosphorus mobility and degree of saturation in oxisol under no-tillage after long-term dairy liquid manure application. Soil Tillage Res. 2018 Apr;177(1):45-53. doi:10.1016/j.still.2017.11.014.

19. Abdala DB, Ghosh AK, Silva IR, Novais RF, Venegas VHA. Phosphorus saturation of a tropical soil and related $P$ leaching caused by poultry litter addition. Agric Ecosyst Environ. 2012 Nov;162(1):15-23. doi:10.1016/j.agee.2012.08.004.

20. Jalali M, Jalali M. Assessment risk of phosphorus leaching from calcareous soils using soil test phosphorus. Chemosphere. 2017 Mar; 171(1):106-17. doi: 10.1016/j.chemosphere.2016.12.042.

21. Gatiboni LC, Smyth TJ, Schmitt DE, Cassol PC, Oliveira CMB. Proposta de limites críticos ambientais de fósforo para solos de Santa Catarina. Boletim Técnico. Lages: CAV/UDESC; 2014 Apr. 38 p. Available from: http://www.cav.udesc.br/arquivos/id_submenu/622/boletim_tecnico_2014_proposta_de_limites_criticos_ambienta is_de_fosforo_para_solos_de_santa_catarina.pdf

22. Nair VD, Harris WG. Soil phosphorus storage capacity for environmental risk assessment. Adv Agric. 2014 Aug;2014(1):1-9. doi: 10.1155/2014/723064.

23. Xi B, Zhai L, Liu J, Liu S, Wang H, Luo C, et al. Long-term phosphorus accumulation and agronomic and environmtal critical phosphorus levels in Haplic Luvisol soil, northern China. J Integr Agric. 2016 Jan;15(1):200-8. doi:10.1016/S2095-3119(14)60947-3

24. Cavaglione JH, Kiihl LRB, Caramorl PHOD. Cartas climáticas do Paraná. Londrina: IAPAR; 2000.

25. Marques R, Motta ACV. Análise química do solo para fins de fertilidade. In: Lima MR de, editor. Manual de diagnóstico da fertilidade e manejo dos solos agrícolas. Curitiba:Departamento de Solos e Engenharia Agrícola; 2003. p. 81-102.

26. Self-Davis ML, Moore PA, Joern BC. Water- or dilute salt-extractable phosphorus in soil. In: Kovar JL, Pierzynski GM, editors. Methods of phosphorus analysis for soils, sediments, residuals and waters. Blacksburg: Virginia Tech 
University; 2009. p. 22-24.

27. Tokura AM, Furtini Neto AE, Curi N, Faquin V, Kurihara $\mathrm{CH}$, Alovisi AA. Formas de fósforo em solo sob plantio direto em razão da profundidade e tempo de cultivo. Pesq Agropec Bras. 2002 Oct;37(10):1467-76. doi:10.1590/S0100-204X2002001000015.

28. Lourenzi CR, Ceretta CA, Cerini JB, Ferreira PAA, Lorensini F, Girotto E, et al. Available content, surface runoff and leaching of phosphorus forms in a typic hapludalf treated with organic and mineral nutrient sources. Rev Bras Ciênc Solo. 2014 Mar-Apr;38(2):544-56. doi:10.1590/S0100-06832014000200019.

29. Boitt G, Schmitt DE, Gatiboni LC, Wakelin SA, Black A, Sacomori W, et al. Fate of phosphorus applied to soil in pig slurry under cropping in southern Brazil. Geoderma. 2018 Jul;321(1):164-72. doi:10.1016/j.geoderma.2018.02.010.

30. Guardini R, Comin JJ, Schmitt DE, Tiecher T, Bender MA, dos Santos DR, et al. Accumulation of phosphorus fractions in typic Hapludalf soil after long-term application of pig slurry and deep pig litter in a no-tillage system. Nutr Cycl Agroecosystems. 2012 Jun;93(1):215-25. doi:10.1007/s10705-012-9511-3.

31. Scherer EE, Nesi CN, Massotti Z. Atributos químicos do solo influenciados por sucessivas aplicações de dejetos suínos em áreas agrícolas de Santa Catarina. Rev Bras Ciênc Solo. 2010 Jul-Aug;34(4):1375-83. doi:10.1590/S0100-06832010000400034.

32. Gessel PD, Hansen NC, Moncrief JF, Schmitt MA. Rate of fall-applied liquid swine manure: effects on runoff transport of sediment and phosphorus. J Environ Qual. 2004 Sep;33(5):1839-44. doi:10.2134/jeq2004.1839.

33. McDowell RW, Sharpley AN. Approximating phosphorus release from soils to surface runoff and subsurface drainage. J Environ Qual. 2001 Mar-Apr;30(2):508-20. doi:10.2134/jeq2001.302508x.

34. Eriksson AK, Ulén B, Berzina L, lital A, Jansons V, Sileika AS, et al. Phosphorus in agricultural soils around the Baltic Sea - comparison of laboratory methods as indices for phosphorus leaching to waters. Soil Use Manag. 2013 Mar;29(s1):5-14. doi:10.1111/j.1475-2743.2012.00402.x.

35. Djodjic F, Mattsson L. Changes in plant-available and easily soluble phosphorus within 1 year after $P$ amendment. Soil Use Manag. 2013 Mar;29(1):45-54. doi:10.1111/j.1475-2743.2012.00436.x.

36. Xue Q, Lu L, Zhou Y, Qi L, Dai P, Liu X, et al. Deriving sorption indices for the prediction of potential phosphorus loss from calcareous soils. Environ Sci Pollut Res Int. 2014 Jan;21(2):1564-71. doi:10.1007/s11356-013-2045-7.

37. Vadas PA, Kleinman PJA, Sharpley AN, Turner BL. Relating soil phosphorus to dissolved phosphorus in runoff: A single extraction coefficient for water quality modeling. J Environ Qual. 2005 Mar-Apr;34(2):572-80. doi:10.2134/jeq2005.0572.

38. Torbert HA, Daniel TC, Lemunyon JL, Jones RM. Relationship of soil test phosphorus and sampling depth to runoff phosphorus in calcareous and noncalcareous soils. J Environ Qual. 2002 Jul-Aug;31(4):1380-7. doi:10.2134/jeq2002.1380.

39. Fischer P, Pöthig R, Gücker B, Venohr M. Phosphorus saturation and superficial fertilizer application as key parameters to assess the risk of diffuse phosphorus losses from agricultural soils in Brazil. Sci Total Environ. 2018 Jul;630(1):1515-27. doi:10.1016/j.scitotenv.2018.02.070.

40. Fischer P, Pöthig R, Venohr M. The degree of phosphorus saturation of agricultural soils in Germany: Current and future risk of diffuse $\mathrm{P}$ loss and implications for soil P management in Europe. Sci Total Environ. 2017 Dec;599600(1):1130-9. doi:10.1016/j.scitotenv.2017.03.143.

41. Sociedade Brasileira de Ciência do Solo - Núcleo Estadual do Paraná. Manual de adubação e calagem para o estado do Paraná. Curitiba: SBCS-NEPAR; 2007. 482 p.

42. Chakraborty D, Nair VD, Chrysostome M, Harris WG. Soil phosphorus storage capacity in manure-impacted Alaquods: Implications for water table management. Agric Ecosyst Environ. 2011 Aug;142(3-4):167-75. doi:10.1016/j.agee.2011.04.019.

(C) 2020 by the authors. Submitted for possible open access publication under the terms and conditions of the Creative Commons Attribution (CC BY NC) license (https://creativecommons.org/licenses/by-nc/4.0/). 